more likely that, when it came to image manipulation, they wouldn't because they couldn't. These constraints led to the accepted standards for publishing quality images: what you got is what you saw. It's not that researchers didn't aspire to perfection - to have obtained images worthy of the admiration of colleagues enhanced your prestige because it proclaimed technical mastery. But the numerous examples of slightly inadequate data continually reminded everyone just how difficult it was not only to perform the perfect experiment, but to acquire the perfect image.

Digital image acquisition and processing tools have removed the physical impediments to perfect images and laid bare the inadequacies of current training practices. Traditions for image handling were not passed down from one generation to the next because there weren't any traditions. Into this vacuum has crept 'beautification' the digital manipulation of properly acquired data for the purpose of making a figure clearer, more perfect and more consistent with the best images yielded in such experiments. Removing dust from a digitized photo with the erasure tool, cropping bands from gels, and playing with fluorescence micrographs to enhance a particular effect are all attempts to show better results than were actually achieved in that run. In all these cases the data are legitimately acquired but then processed to yield an idealized image.

In Nature's view, beautification is a form of misrepresentation. Slightly dirty images reflect the real world. Accordingly — and after consulting with technical experts - the Nature family of journals has developed a concise guide to appropriate image handling (www.nature.com/nature/authors/submissions/images), which will soon be incorporated into Guides for Authors.

In short, any digital technique that isn't applied to the entire image is suspect and needs to be explicated to the reader in the Methods or Supplementary Information. Authors should detail the instrument settings and the software manipulation that was performed on figures in an additional table in Supplementary Information. The fewer manipulations, the easier it will be for authors, referees and readers. Any changes made to misrepresent the data in the original image (such as boosting the contrast to eliminate backgrounds, making a collage

"In short, any digital
technique that isn't applied
to the entire image is
suspect and needs to be
explicated to the reader."
of cells in a micrograph to show more cells in a visual field, or removing possibly informative bands in narrowly cropped gels) are of course strictly off limits.

We should conspire to end the fetish of the perfect image. Let's all get a little more 'real'. Nature is happy to work with others to aid the promulgation of image standards that we can all live with. The responsibilities of the institutes that train students, of the investigators who use their labour, and of the journals that publish the data can be better defined. Finding ways to regain our trust in scientific images is a goal on which we can all agree.

\section{Diplomatic incident}

\section{Japan has fumbled its row with North Korea over tests to identify abductees.}

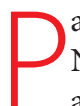
arties were held last week to celebrate the 64th birthday of North Korean leader Kim Jong-il — even in Japan, which has a troubled history with its near-neighbour. In Tokyo, the General Association of Korean Residents in Japan, which mainly comprises ancestors of Koreans who were forcibly taken to Japan during its 35-year occupation of the Korean Peninsula, held a party to mark the occasion. And those who attended were able to toast a recent diplomatic victory over Japan, in which the North Korean government was, incredibly, allowed to claim for itself the mantle of scientific objectivity.

The victory concerns the status of DNA tests conducted in Japan in 2004 on human remains that had been passed on from North Korea to Japan. North Korea said the remains were those of Megumi Yokota, a Japanese citizen that North Korea has admitted to kidnapping in 1977. Based on the DNA tests, however, Japan insists that the remains are those of someone else, and continues to demand an account of what really happened to Yokota.

But last January, in an interview with Nature, the scientist who carried out the DNA tests admitted that they were not conclusive (see Nature 433, 445; 2005). He has since been prevented from giving a full and open account of the matter.

Japan now needs to either produce evidence to back up its previous claims that the DNA tests were conclusive, or admit they weren't, perhaps as a result of a lack of DNA in the incinerated remains.

But admitting such an error is something to which Japanese officials are inherently adverse. They may fear losing face - but such a loss would only be temporary, and coming clean would strengthen Japan's position in the longer term. There would still be no solid evidence to support North Korea's claim that Yokota was cremated. Japan could then continue to press North Korea for a plausible account of what really happened to Yokota and many other kidnapped Japanese nationals.

Instead, as things stand, the issue of the DNA tests on the bones has presented Japan with a thorny diplomatic problem. And the North Koreans are taking full advantage.

At bilateral talks two weeks ago, North Korea invited Japan to arrange a joint meeting of researchers to discuss the DNA
"Japan now needs to either produce some evidence to back up its claims that the DNA tests were conclusive, or admit that they weren't." analysis. Japan declined the offer, continuing to insist that its original interpretation was correct. This left the guests at Kim's birthday party gleefully dancing on their firm scientific ground: "We just want the truth to come out," they gloated. "We want to proceed scientifically."

Japanese officials need to learn from their mistake. In jostling with Kim's unpleasant regime, they need to be sure to retain the moral high ground. Public statements based on the wrongful interpretation of scientific data are liable to backfire. Refusing to acknowledge such problems at the first available opportunity tends to compound them, resulting not just in a loss of face, but of credibility. 